\title{
Tourism Impacts; Threats and Opportunities in Barili, Cebu
}

\author{
Ma. Leslie B. Basallo ${ }^{1}$ \\ ${ }^{1}$ Cebu Technological University-Barili Campus, Cagay, Barili, Cebu Philippines
}

\begin{abstract}
Tourism has been widely known as one of the income generating industries worldwide. With the ongoing demand for travel and tourism, destination areas need to keep abreast with the standard of service they offer to tourists. However, as the industry grows, tourism destinations are vulnerable to both advantage and disadvantage. Thus, this study assessed the threats and opportunities of tourism in the identified tourism destinations in the Municipality of Barili, Cebu. Opportunities such as employment generation, increase in investment in area by private and public organizations, entrepreneurial development, increase in standard of living, increase in foreign exchange earnings, public facility development, infrastructure development, social relation development, increase in cultural activities, increase in pride, cultural exchange, appreciation of local culture, positive change in people's lifestyle, behavior and values have a Neutral degree of responses perceived by the respondents. Moreover, threats for tourism also needs to be examined such as increase in property prices, nonresidents are getting benefits, increase in cost of living, commercialization of activities, dilution of local languages, increase in crime, increase in social conflicts, social dislocation, increase in crowding and congestions, prostitution, inflation, pollution and loss of cultural identity as these would hinder the industry's success and growth instead of providing positive change in the locals in Barili.
\end{abstract}

Keywords: Tourism Destination, Tourism Industry, Threats, Opportunities

\section{Introduction}

The Municipality of Barili located at the southwestern part of Cebu has been opening its doors towards strengthening its tourism industry. For the last five (5) years, the drastic change of tourism activities attracts more tourists to come and visit several tourism attractions in the community. From natural, man-made, cultural, historical, special activities and festivals, these give birth to a better tourism cycle. The town aside from the tourism attractions also boosts its palatable local delicacies such as relyenong monngos, salbaro, tinapay, puto balanghoy,pinato and bibingka. The rise of tourism gives locals more opportunities to sell and market their local products and services to domestic and foreign tourists. These attractions and activities keep the Municipality of Barili on the roadmap of tourism development in Cebu. Nevertheless, with the effort and creativeness of its tourism personnel, its future development would come a long way towards successful tourism activity in the province.

Further, the significance to assess the threats and opportunities of tourism would help strengthen the industry not only as one of the income generating resources but also as a means to improve the lives of the people living in the Barili.

\section{Literature Review}

Tourism creates opportunities which includes increase in local income, employment opportunities and business linkage. When tourists travel, tourist spending on local products and services takes into account thereby increasing the economic activity in the area. White, Sean. 2010. Measuring Tourism Locally; Guidance Note: Local Economic Impact Modelling Approaches. Tourism also needs to be controlled so not to create irreversible damage to the environment, cultural and historical heritage and other physical and intangible resources in the community. (Engelhardt, Richard UNESCO Regional Advisor for Culture in Asia and the Pacific vi).

Generally, travel and tourism is huge as it is a good avenue for business opportunities and investments, creating more jobs and other entrepreneurial development in the country. Aside from that tourism protects 
heritage and cultural values through preservation and conservation of its resources. (2015, Scowsill David, President, WTTC).

Against this background, the proposed study will investigate the threats and opportunities of the tourism industry in the Municipality of Barili. This would strengthen the industry not only as one of the income generating resource but also as a means to improve the social lives of the people living in the Barili.

\section{Objectives}

This study the threats and opportunities of the tourism industry in the Municipality of Barili. Specifically this will answer the following questions:

1. Identify the threats and opportunities of tourism in the Municipality of Barili'

2. Assess resident's perception on the positive and negative impacts of tourism in the Municipality of Barili.

3. Recommend ways and strategies to improve the tourism industry in the municipality.

\subsection{Materials and Methods}

This study used quantitative descriptive research design. It is anchored on the study of Sawant, Madhuri on the Socio-Economic Impacts of Tourism Development at Aurangabad District. Modified and adopted survey questionnaires and interview guides were the main instruments of the study.Primary data other pertinent records or archival documents were taken from the Tourism Legislative Office in the Municipality

The opportunities of tourism are identified as employment generation, increase in investment in area by private and public organizations, entrepreneurial Development, Increase in a standard of living, increase in foreign exchange earnings, public facility development, infrastructure development, cultural conservation, social relation development, increase in cultural activities, increase in pride, cultural exchange, appreciation of local culture, and positive change in people's lifestyle, behavior and values.

Thus, tourism threats were identified into increase in property prices, nonresidents are getting benefits, increase in cost of living, commercialization of activities, dilution of local languages, increase in crime, increase in social conflicts, social dislocation, increase in crowding and congestions, prostitution, inflation, pollution and loss of cultural identity. Moreover, 5 point Likertscale was used to measure the value of each tourism characteristics which represents strongly agree, agree, neutral, disagree, and strongly disagree.

\subsection{Results and Discussions}

The Municipality of Barili is composed of forty-two (42) barangays, eight (8) of which were officially recognized as tourism destinations in the community. These barangays are Barangay Bolocboloc, Campangga, Dakit, Luhod, Mantalongon, Mayana, Poblacion and Sayaw. Among others, these destinations primarily benefit the tourism industry since it is where major tourism attractions are found. Major changes and developments have been observed by local residents and tourists particularly $\mathrm{n}$ these tourism sites. The tourism attractions found within these areas are further categorized into natural attractions, man-made, cultural, historical, festivals and other special activities.

As per survey, there are still unknown tourists destinations or attractions in the municipality. Consequently, the local government office is presently monitoring these sites in order to gain income and opportunities in the area

\subsection{Perceived Tourism Impacts using Relative Frequency Percentage}

This presents how many times the respondents have chosen the item characteristics based on their perception as to strongly agree, agree, neutral, disagree and strongly disagree. For the positive socio-economic impacts, employment generations of tourism have gained $46.81 \%$ majority for those who strongly agreed while $31.81 \%$ agreed, $16.81 \%$ were neutral and only $1.94 \%$ strongly disagree. This means that tourism creates more job 
opportunities for residents in the community. With regard to increase in investment opportunities in area by private and public organizations, 38.19\% of the respondents agree, while $35.42 \%$ strongly agree.20.14\% remained neutral, while $2.64 \%$ disagreed and only $0.14 \%$ strongly disagrees. As with entrepreneurial development a higher percentage of the respondents strongly agreed on the increase of small scale businesses in the community with $40.69 \%$, followed by those who agreed with $32.69 \%$, while $19.86 \%$ were neutral and $3.19 \%$ disagreed. In the case of increase in the standard of living 36.39 percent agreed that they have somehow felt the change in their standard of living, while $29.17 \%$ strongly agreed on this matter, and $26.11 \%$ remained neutral. As to those who disagreed there were a portion of $3.61 \%$ and a remaining $0.28 \%$ for those who strongly disagreed. With regard to the increase in foreign exchange earnings, majority agreed on this with $35.42 \%$ while $28.89 \%$ strongly disagreed. The remaining $26.81 \%$ were neutral and $4.31 \%$ said that they have disagreed. For public facility development, majority agreed that they have observed major developments on public facilities within their community, $22.50 \%$ were neutral while $4.44 \%$ disagreed and remaining $0.28 \%$ strongly disagreed. As per the infrastructure development, $38.19 \%$ of the respondents agreed while $29.31 \%$ strongly agrees, those who remained neutral were $22.64 \%$ and $4.17 \%$ disagreed and a portion of $0.28 \%$ of the respondents strongly disagreed.

Moreover, on the aspect of cultural conversation majority have agreed that tourism contributed to the conversation of cultural heritage in the community, $27.50 \%$ strongly agreed, while $20.42 \%$ neither agrees or disagrees and $4.17 \%$ disagreed while $0.14 \%$ strongly disagreed on this aspect. With regards to social relation development majority of the respondents agreed with $36.11 \%$, while $30.97 \%$ strongly agreed, $23.33 \%$ were neutral and $3.06 \%$ disagreed. Heritage conservation aspects also have a higher percentage for those who strong agreed with $35.97 \%$, while $26.11 \%$ agreed, $20.83 \%$ were neutral, $5.69 \%$ disagreed and only $0.28 \%$ strong disagreed. The increase in cultural activities because of tourism also gained positive responses with $35.28 \%$ of the respondents agreed, and $27.08 \%$ strongly agreed, while $26.81 \%$ remained neutral, $3.33 \%$ disagreed and none of the respondents strongly disagreed. The increase in pride by the locals because of tourism industry has a higher positive response with $39.17 \%$ for those who agreed and $22.64 \%$ who strongly agreed, $25.69 \%$ have neutral responses and a remaining of $3.89 \%$ disagreed. As with the cultural exchange $35.0 \%$ agreed and $25.14 \%$ strongly agreed, $28.75 \%$ were neutral and $3.75 \%$ disagreed. On the appreciation of local culture most of the respondents agreed with $35.83 \%$ while $22.64 \%$ strongly agreed, $26.39 \%$ remained neutral and $3.75 \%$ disagreed with $0.14 \%$ strongly disagreed. Lastly, on the aspect of positive change in people's lifestyle, behavior and values because of tourism, majority of the respondents agreed on this with $32.36 \%$ while $29.17 \%$ strongly agreed, $26.11 \%$ remained neutral, and $2.92 \%$ of the respondents disagreed.

On the perceived threats of tourism, the respondents have various responses. With increase in property prices, $55.28 \%$ disagreed while $8.47 \%$ strongly disagreed. This implies that tourism has not brought increase in property prices in destination barangays in the municipality as perceived by the residents. While $24.86 \%$ remained neutral, only $3.42 \%$ agreed on this and $0.42 \%$ strongly agreed. On the aspect of nonresidents are getting benefits from tourism majority of the respondents disagreed with $49.17 \%$ while $18.89 \%$ strongly disagreed, primarily because the residents on the respective barangay where a tourists attraction is located have benefited from the income brought by tourists visiting the place, $17.22 \%$ remained neutral and only $2.08 \%$ agreed with $0.69 \%$ for those who strongly agreed. With the increase in cost of living, majority of the respondents also disagreed with $51.94 \%$ while $15.97 \%$ strongly disagreed, a remaining of $18.19 \%$ for neutral responses and $2.50 \%$ for those who agreed and $0.28 \%$ for those who strongly agreed. As per commercialization of activities, $45.08 \%$ disagreed and $15.97 \%$ strongly disagreed, while $17.64 \%$ remained neutral and $3.33 \%$ agreed with $0.14 \%$ strongly agreed. Dilution of local languages because of tourism have gained $47.08 \%$ for those who disagreed while $19.86 \%$ for those who strongly disagreed, $16.53 \%$ remained neutral, with a remaining of $2.64 \%$ for those who agreed and only $0.14 \%$ for those who strongly disagreed. Most of the respondents have disagreed on the increase of crime because of tourism with $41.25 \%$ while $24.17 \%$ for those who strongly disagreed, $19.72 \%$ remained neutral, $2.22 \%$ agreed on this with only $0.28 \%$ strongly agreed. With regard to the increase in social conflicts most of the respondents disagreed on this with $45.69 \%$ with $20.97 \%$ strongly disagreed, while $16.25 \%$ 
were neutral and only $1.53 \%$ agreed. With regard to social dislocation $42.22 \%$ disagreed while $28.61 \%$ strongly disagreed, $16.81 \%$ remained neutral and only $1.81 \%$ agreed. As per environmental damage majority disagreed with $49.03 \%$ and $21.81 \%$ strongly disagreed, $15.83 \%$ were neutral and $2.22 \%$ agreed and only $0.14 \%$ strongly agreed. Increase in crowding and congestions remained not an issue with $46.25 \%$ of the respondents who disagreed and $24.44 \%$ strongly disagreed, $15.97 \%$ remained neutral and only $1.94 \%$ agreed. On the , issue of prostitution majority of the respondents disagreed with $37.22 \%$ while $38.19 \%$ disagreed, and $12.78 \%$ were neutral and only $1.81 \%$ agreed. As per inflation still the respondents response have higher percentage on those who disagreed with $45.0 \%$, while $38.25 \%$ strongly disagreed, the remaining $14.03 \%$ were neutral and $1.25 \%$ agreed and $0.14 \%$ strongly agreed. In the case of pollution $40.56 \%$ disagreed that tourism contributes to this, while $31.25 \%$ strongly disagreed, $14.58 \%$ were neutral and $8.06 \%$ agreed.

\subsection{Summary of Findings}

This section presents the summary of findings and conclusions drawn from the research investigation. The recommendations will serve as guidelines for the proposed tourism development plan.

1. Based on the Visitor Attraction Record (VAR), the number of tourists arrivals in the Municipality of Barili for the last three (3) years have significantly increases from 212,048 tourists (2015), to 335,182(2016) and 735,381 (2017) for a total of 1,282,611 tourists arrivals both foreign and local.

2. There are only eight (8) identified tourist destinations in the Municipality of Barili namely Barangay Bolocboloc, Campangga, Dakit, Luhod, Mantalongon, Mayana, Poblacion and Sayaw. These barangays have possessed the different tourist's attractions that attract the tourists to visit the municipality. Though there are other tourists attractions found in the locality, they are still not famous and needs more development.

4. The respondent's perception on opportunities of tourism has a weighted average mean of 3.73 which means Neutral. These characteristics include employment generation, increase in investment in area by private and public organizations, entrepreneurial development, increase in standard of living, increase in foreign exchange earnings, increase in foreign exchange earnings, public facility development, infrastructure development, cultural conservation, social relation development, heritage conservation, increase in cultural activities, increase in pride, cultural exchange, appreciation of local culture, positive change in people's lifestyle, behavior and values. While the respondents perception on the negative socio-economic impact s of tourism have a weighted average mean of 1.76 which means Strongly Disagree. These characteristics include increase in property prices, nonresidents are getting benefits, increase in cost of living, commercialization of activities, dilution of local languages, increase in crime, increase in social conflicts, social dislocation, environmental damage, increase in litter and garbage, increase in crowding and congestions, prostitution, inflation, pollution and loss of cultural identity.

\section{Conclusions}

Based on the results and findings of the study, the threats and opportunities of the tourism in the Municipality of Barili were viewed to be Neutral by the respondents. This can be assumed that the respondents still has to validate and experience more its positive impacts in order to fully conclude that tourism brings positive opportunities in the lives of the people in the municipality. Nevertheless, there is no evidence or support that negative impacts of tourism are existing or have been experienced by the residents in the community. Still, tourism holds the opportunity to boost the socio-economic development of the people in the Municipality of Barili.

\section{Recommendations}

Based on the results and finding of the study, the following are its recommendations: 
1. Creation of a Tourism Development Framework by the Local Government Tourism Office which serves as a tool in the planning and implementation of future tourism projects and developments in the Municipality of Barili.

2. Improvement of tourism destination facilities and services to meet the standard service quality of tourists and guest visiting the area.

3. Encourage and support locals to promote local products and services to strengthen small and medium enterprise developments.

4. Community involvement and participation in the creation of tourism development plans in order to strengthen and sustain the tourism industry in the municipality.

5. The Municipality of Barili possess a lot of infamous tourist attractions hence, it is recommended that the tourism office in collaboration with the respective barangay officials may register these existing tourists attractions in order to be officially part of its tourism attractions through promotions and marketing that could attract more tourists to come and visit the Municipality.

6. It is recommended that the tourism legislative office in Barili may conduct or include the socioeconomic status of the tourists visiting in the locality to help measure the socio-economic impact of the tourism industry in the municipality

\section{References}

[1] Sawant, Madhuri: BabasahebAmbedkar; Socio-Economic Impacts of Tourism Development at Aurangabad District; Marathwada University; https://www.researchgate.net/publication/, 2017.

[2] Dandan, Cora ,Tourism Officer, Local Government Office, Municipality of Barili, 2017.

[3] The Way Forward; 2017-20 Provincial Product Development Plan: Tourism , Culture, Industry and Innovation Government of Newfoundland and Labrador,2017.

[4] Department of Tourism (DOT) Philippines website. [Online]. Available: http://www.dot.gov.ph , 2017.

[5] International Journal website. [Online]. Available: http://www.internationaljournalssrg.org/IJEMS/index.html, 2017.

[6] Measuring Tourism's Impact- a Pilot Study in Cyprus Methodology; PricewaterhouseCoopers LLP', 2015.

[7] Competitiveness of Philippine Tourism in Terms of ASEAN Tourism Strategic Plan 2011-2014; Williams, MC. International Journal of Education and Social Science; 2014.

[8] Cherry Pilapil-Añasco1, Joy C. Lizada2 (2014); Philippine Tourism: Evolution towards Sustainability, SHS Web of Conferences 12, 0103 , 2014.

[9] Tabatha Reefs Natural Park and World Heritage Site Comprehensive Tourism Management Plan; Tubbataha Protected Area Management Board, Tubbataha Management Office (2013);

[10] Vide-Korez, Romana; Enforcing Sustainability Principles in Tourism via Creative Tourism Development; Journal of Tourism Challenges and Trends',2013.

[11] Cacho, Katlene, Challenging Year for Tourism, Sunstar.cebu.phillipines, 2013.

[12] Kaewta Muangasame1 \& Siyathorn Khunon2, Enhancing Tourism Competitiveness of Hong Kong via Tourism Planning: A Comparative Case Study between Hong Kong and Singapore; Asian Social Science; Vol. 9, No. 17; 2013ISSN 1911-2017 E-ISSN 1911-2025, Published by Canadian Center of Science and Education’ ,2013.

[13] Rieder, Ludwig Strategic Tourism Planning for Sustainable Destinations and Sites; 6th UNWTO Executive Training Program, Bhutan, 2012.

[14] Kim, Namhyun ;Tourism Destination Competitiveness, Globalization and Strategic Development from a Development Economics Perspective; Urbana, Illinois; (2012);

[15] The National Tourism Development Plan: Strengthening the Philippines Strategic Planning Process: 6th UNWTO Executive Training Program 25-28 June 2011; Bhutan: Department of Tourism; 2011 
[16] Joan C. Henderson, Tourism Development and Politics in the Philippines; Tourismo: An International Multidisciplinary Journal of Tourism, Volume 6, Number 2, Autumn 2011, pp. 159-173, 2011.

[17] White, Sean. Measuring Tourism Locally; Guidance Note: Local Economic Impact Modeling Approaches; 2010.

[18] Dawe, Neil; Torbay Comprehensive Tourism Plan: Tract Consulting, Inc. 2010.

[19] Mahmoud Yasin, Jafar Alavi, Sallem Koubida, Sallem Koubida, An assessment of thecompetitiveness of the Moroccan tourism industry; Benchmarking: An International Journal; 2010.

[20] Myles, A., Carter R; Measuring the Economic Impact of Tourism and Special Events: Lessons from Mississippi; Southern Agricultural Economics Association Annual Meeting, Atlanta, Georgia., 2009.

[21] Erdogan Koc , A review of country tourism competitiveness, research performance and Overall country competitiveness, Dogus University, Istanbul, Turkey; 2009.

[22] UNWTO, OECD, Eurostat, International Recommendations on Tourism Statistics. , (Research Resolutions and Consulting Ltd. 2007; Guidelines: Survey Procedures for Tourism Economic Impact Assessments of Gated, Permanent Attractions); 2009 